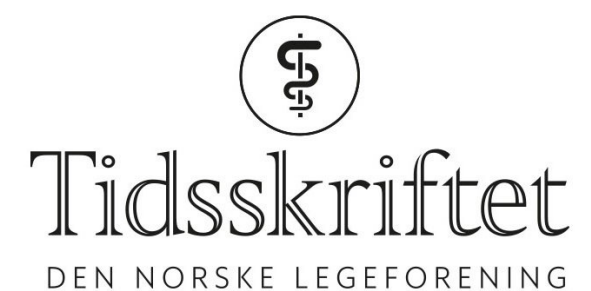

DEN NORSKE LEGEFORENING

\title{
Vi trenger både høyrisiko- og befolkningsrettede strategier
}

KOMMENTAR

FREDRIK A. WALBY

E-post: fredrik.walby@medisin.uio.no

Fredrik A. Walby er forsker og psykologspesialist.

MARTIN Ø. MYHRE

ANINE T. KILDAHL

Ingen av forfatterne har oppgitt interessekonflikter.

Ekeberg og Hem drøfter i sin kronikk mange viktige momenter. Vi er enige i behovet for mer klinisk forskning samt påpekningen av nødvendigheten av finansiering og evaluering av handlingsplaner på feltet. Imidlertid ser forfatterne bort fra en av de viktigste risikogruppene for selvmord i psykisk helsevern, og dette krever en kommentar.

Ekeberg og Hem refererer vår metaanalyse av internasjonale studier som viste et samlet estimat for kontakt med psykisk helsevern året før selvmord på $25,7 \%$ (1). Vi fant også en markert heterogenitet mellom ulike studier, som best forklares med forskjellene mellom ulike land og helsesystemer. Videre estimerer Ekeberg og Hem at det kun er ca. 30 selvmord under innleggelse i psykisk helsevern hvert år, og at bedre forebygging under innleggelse derfor kun marginalt vil påvirke selvmordsraten.

Vi publiserte i 2018 den første detaljerte beskrivelsen av selvmord under og etter behandling i psykisk helsevern og tverrfaglig spesialisert rusbehandling i Norge 2008-2015 (2). I denne studien er andelen som har vært i kontakt med psykisk helsevern de siste årene nesten dobbelt så høyt som estimatet fra metaanalysen, nærmere $50 \%$. Viktigere er det at $67 \%$ av alle som døde etter kontakt med psykisk helsevern for voksne hadde minst én innleggelse siste år, og at halvparten av disse døde i løpet av zo dager etter innleggelsen. Opphopningen av selvmord etter utskrivelse er velkjent og konsistent funnet i tallrike studier. Forebyggingspotensialet innenfor psykisk helsevern er dermed betydelig større enn hva Ekeberg og Hem anfører. Totalt har om lag 250 personer vært i kontakt med psykisk helsevern eller tverrfaglig spesialisert rusbehandling siste år før selvmord - hvert eneste år i perioden - og rundt 150 av disse har vært innlagt i psykisk helsevern siste leveår. Om man $\emptyset n s k e r$ å redusere selvmordsratene i Norge, er pasienter i disse tjenestene en av gruppene som må prioriteres, ikke minst i tiden etter utskrivelse.

Ekeberg og Hem anbefaler å ta lærdom av forebygging av hjertesykdom, der befolkningsrettede tiltak som kjent har vært viktige. Det er imidlertid tvilsomt om 
befolkningsrettet forebygging basert på Geoffrey Roses teori (3) er en tilstrekkelig tilnærming i en situasjon hvor risikofaktorene er så ulikt fordelt som for selvmord. I tillegg mangler vi i suicidologien fremdeles en empirisk dokumentert modifiserbar underliggende faktor (jamfør kolesterol og hjertesykdom) som kunne danne basis for en slik populasjonsstrategi. Basert på dagens kunnskapsstatus må selvmordsforebygging inneholde både høyrisiko- og befolkningsrettede strategier.

\section{LITTERATUR:}

1. Walby FA, Myhre MØ, Kildahl AT. Contact With Mental Health Services Prior to Suicide: A Systematic Review and Meta-Analysis. Psychiatr Serv 2018; 69: 751-9. [PubMed][CrossRef]

2. Walby FA, Myhre MØ, Kildahl AT. 1910 døde pasienter. Selvmord i psykisk helsevern og tverrfaglig spesialisert rusbehandling 2008 til 2015 - en nasjonal registerstudie. Oslo: Nasjonalt kartleggingssystem for selvmord i psykisk helsevern og tverrfaglig spesialisert rusbehandling, 2018. https://www.med.uio.no/klinmed/forskning/sentre/nssf/kartleggingssystemet/dokumenter/nssf_kartl eggingssystemet_rapport_web_korrigert_p.pdf Lest 16.8.2019.

3. Rose G. Sick individuals and sick populations. Int J Epidemiol 1985; 14:32-8. [PubMed][CrossRef]

Publisert: 9. september 2019. Tidsskr Nor Legeforen. DOI: 10.4045/tidsskr.19.0519

(C) Tidsskrift for Den norske legeforening 2020. Lastet ned fra tidsskriftet.no 